\title{
Characterization of Isolates of Phytophthora colocasiae Collected from Andhra Pradesh and Telangana Causing Leaf Blight of Taro
}

\author{
G. Padmaja ${ }^{1^{*}}$, G. Uma Devi ${ }^{1}$, B. Kanaka Mahalakshmi ${ }^{3}$ and D. Sridevi ${ }^{2}$ \\ ${ }^{1}$ Department of Plant Pathology, Prof Jayashankar Telangana State Agricultural University, \\ Rajendranagar, Hyderabad - 500 030, Telangana, India \\ ${ }^{2}$ Department of Entomology, College of Agriculture, Prof Jayashankar Telangana State \\ Agricultural University, Rajendranagar, Hyderabad - 500 030, Telangana, India \\ ${ }^{3}$ Vegetable Research Station, Sri Konda Laxman Telangana State Horticulture University, \\ Agriculture Research Institute, Rajendranagar, Hyderabad - 500 030, Telangana, India \\ *Corresponding author
}

A B S T R A C T

\begin{tabular}{|c|}
\hline Keywords \\
\hline $\begin{array}{l}\text { Leaf blight, } \\
\text { Phytophthora } \\
\text { colocasiae, } \\
\text { sporangium, oospore, } \\
\text { culture medium }\end{array}$ \\
\hline Article Info \\
\hline $\begin{array}{l}\text { Accepted: } \\
17 \text { September } 2017 \\
\text { Available Online: } \\
10 \text { October } 2017\end{array}$ \\
\hline
\end{tabular}

Keywords

Introduction

Taro [Colocasia esculenta (L.) Schott] a tropical aroid is an important staple crop in the developing countries especially in Africa and South East Asian countries. Leaf blight caused by Phytophthora colocasiae Raciborski is the most important disease of Taro and was recorded for the first time by Butler and Kulkarni (1913) in India. Leaf blight has become a limiting factor for production in all taro growing areas in India moderate to severe form causing $25 \%$ to $50 \%$ yield loss every year (Misra et al., 2007).
Leaf blight disease is prevalent in almost all the major taro growing districts of Andhra Pradesh and Telangana with varying intensities on different varieties causing yield loss of 10-55 per cent (Laxmi et al., 2012). The disease appears with the onset of monsoon and spreads the entire field during rainy season through zoospores and sporangia (Misra et al., 2007). Reports have revealed, however, that $P$. colocasiae is relatively short lived in infected leaf tissue like any other foliar pathogen of taro. The fungus seems to 
have a poor competitive saprophytic ability. This contributes to the lack of success in isolating and growing $P$. colocasiae in an artificial medium. In order to culture the fungi in the laboratory, it is necessary to supplement in the medium, those essential elements and compounds needed for their growth and other metabolic processes. Hence different media were tried in the present investigation to select the best medium suitable for the growth of the pathogen.

Also, we studied the variation in growth and sporulation among $P$. colocasiae isolates from processing taro fields. The objective of this study was to investigate cultural and morphologic variation among isolates of $P$. colocasiae isolated from taro fields of different regions.

\section{Materials and Methods}

\section{Isolation and identification of the pathogen}

Diseased leaves showing typical symptoms of Taro plants were collected from different Taro growing areas of Andhra Pradesh and Telangana (ARI, Rajendranagar, Hyderabad, East and West Godavari districts) (Table 1). These leaves were put in sterilized polythene bags and brought to the laboratory for isolation and identification of the organism involved. Taro leaves showing typical symptoms of the disease were selected and washed with sterile water.

The surface sterilized leaf bits were transferred aseptically into sterilized Petridishes containing solidified carrot agar medium and incubated at $18 \pm 2^{\circ} \mathrm{C}$. After 3 days of incubation mycelial growth was absorbed along with diseased leaf bits. Hyphal tips from the advancing mycelia were transferred to the carrot agar medium slants. Also studied different composition of media viz., Potato Dextrose Agar (PDA), Carrot Potato Agar (CPA), V8 agar, Host Leaf
Extract Agar (HLA), Corn Meal Agar (CMA), Papaya Sucrose Agar (PSA) were used along with Carrot agar medium for investigation of cheap source and suitable medium for mycelial growth of Phytophtora colocasiae. The isolated pathogen was identified as Phytophthora colocasiae based on its mycelial and sporangial characters through standard mycological keys (Waterhouse, 1963; Hemmes, 1993) and by CMI descriptions.

\section{Pathogenicity test}

The pathogenicity test was conducted in pots under glass house. The taro variety Satamukhi susceptible to Phytophthora colocasiae leaf blight disease was raised in pots and 20 day old culture grown on $\mathrm{CA}$ broth suspension containing zoospores was inoculated to taro plant at 3-5 leaf stage with hand sprayer and covered with polythene covers.

\section{Variability studies}

\section{Morphological characteristics}

The morphology of mycelium, sporangium, oospore of Phytophthora were studied in seven day old culture of each isolate grown on carrot potato agar medium and stained with 0.1 per cent lacto phenol cotton blue and observed under compound microscope (40X). Observations on size and shape of sporangium, presence of papillae, size of Oospore and Zoospore were recorded.

\section{Cultural characteristics}

Observation on colony colour, growth rate, was recorded at $24 \mathrm{hrs}$ interval and mycelial dry weight of each isolate was recorded at 7 days after incubation at $18 \pm 2{ }^{\circ} \mathrm{C}$. Characteristics like sporulation and colour of spore were observed and recorded at 10 days after incubation. 


\section{Colony diameter and growth rate per day}

Twenty $\mathrm{ml}$ of carrot potato agar medium was poured in sterilized Petriplates and allowed to solidify. Mycelial disc of $5 \mathrm{~mm}$ diameter were cut from the margin of the 7 day old culture of Phytophthora colocasiae placed in the center of the Petriplate under aseptic conditions. The plates were incubated for 8 days in an incubator at $18 \pm 2^{\circ} \mathrm{C}$ and the diameter of the colony was measured and recorded. Three replications of each isolate were maintained for the study. Growth rate per day of each isolate was calculated by dividing the colony diameter with number of days kept for incubation.

\section{Dry weight of mycelium}

The dry weight of the mycelium of each isolate fifty $\mathrm{ml}$ of carrot potato agar both was poured in $150 \mathrm{ml}$ conical flask, plugged and sterilized. Mycelial disc of $5 \mathrm{~mm}$ diameter was cut from the margin of the seven day old culture of each isolate of the pathogen and transferred to the conical flask containing the sterilized medium under aseptic condition.

The flasks were incubated at $18 \pm 2^{\circ} \mathrm{C}$ in an incubator for 8 days. The mycelial mat was removed aseptically, washed thoroughly with distilled water and dried in blotters and kept in an oven at $50^{\circ} \mathrm{C}$ for 12 hours. Dry weight of the mycelium of each isolate was taken and recorded using digital electronic balance.

\section{Length, width and size of sporangium}

Morphological characters such as length, width and the size of sporangium ( $\mathrm{L} \times \mathrm{B}$ ) were measured by using micrometer.

\section{Results and Discussion}

The disease samples of leaf blight of Taro were collected from farmer's fields at
Kovvuru (West Godavari), Bahadurguda, (Ranga Reddy), Rajendranagar (Hyderabad), and Thiruvananthapuram (Kerala) (Table 1). The leaves showing typical symptoms of leaf blight were surface sterilized and kept on carrot agar medium for isolation of the pathogen. The pathogen isolated on carrot agar (CA) medium was identified with the help of descriptions given by Waterhouse (1963). The colony was submerged or fluffy and rosette in its growth and the colour was whitish or dull white. Mycelium was aseptate, hyaline, $1 \mu \mathrm{m}$ in width. Sporangiophore was simple, aseptate, hyaline and the sporangia were hyaline, ovoid, and semipapillate. Based on colony character and sporangial nature the pathogen isolated was identified as Phytophthora colocasiae. The characteristics of the pathogen were similar to the descriptions given by Waterhouse (1963).

The pathogen was further sub cultured on carrot agar medium and the culture was purified by using hyphal tip method and kept on carrot agar medium slants and preserved at $18+2^{0} \mathrm{C}$ for further studies

Effect of different media on the growth of Phytophthora colocasiae

In order to culture the fungi in the laboratory, it is necessary to supplement in the medium, those essential elements and compounds needed for their growth and other metabolic processes. Neither all media are equally good for all fungi nor there will be an artificial medium on which all fungi grow. Hence different media were tried in the present investigation to select the best medium suitable for the growth of the pathogen. Eight different media viz., Potato Dextrose Agar (PDA), Carrot Potato Agar (CPA), Carrot Agar (CA), Papaya Sucrose Agar (PSA), Oat Meal Agar (OMA), Host Leaf Extract Agar (HLEA), Corn Meal Agar (CMA) and Water Agar (WA) were used. 
The growth of the pathogen Phytophthora colocasiae on different media was recorded 7 days after inoculation and the results are presented in Table 2 . The results revealed that among all the media tested, maximum growth of the pathogen was recorded on Carrot Agar (86 $\mathrm{mm})$, followed by Carrot Potato Agar (CPA) medium $(79 \mathrm{~mm})$, whereas minimum growth of the pathogen was recorded on PDA medium $(22 \mathrm{~mm})$ and Corn Meal Agar medium $(29 \mathrm{~mm})$ Table 2. Hence the pathogen was maintained on carrot agar medium for conducting further studies.

Palomar et al., 1999 was studied different artificial media for sporsngisl production of Phytophthora colocasiae they reported V-8 juice agar was best medium for growth and reproduction. In their study V8 juice agar was given $83.47 \mathrm{~mm}$ of mycelia growth compare to other media viz., V8 juice agar II(79.90 $\mathrm{mm})$, Onion agar $(\mathrm{OA})(76.90 \mathrm{~mm})$, Potato dextrose agar (PDA) $(51.46 \mathrm{~mm})$

\section{Pathogenicity}

The pathogenicity test was conducted in pots in glasshouse as described under materials and methods. The taro variety Satamukhi susceptible to leaf blight disease was raised in pots and 20-day-old culture grown on CA broth suspension containing zoospores was inoculated on taro plant at 3-5 leaf stage with hand sprayer and covered with polythene covers. The plants showed typical symptoms of leaf blight 5 days after inoculation.

The pathogen was isolated on CA medium and the culture characteristics were similar as that of the original culture. Hence the pathogenicity was proved.

Morphological and colony characteristics of Phytophthora colocasiae of Taro

The isolates were morphologically characterized by measuring the shape, size, length and width of 100 sporangia at a magnification of $40 \mathrm{X}$.

\section{Colony characteristics of different isolates} of Phytophthora colocasiae

Colony characters of 4 isolates of Phytophthora colocasiae designated as $\mathrm{PC}_{1}$ (Rajendranagar), $\mathrm{PC}_{2}$ (Bahadurguda), $\mathrm{PC}_{3}$ (Thiruvananthapuram), $\mathrm{PC}_{4}$ (Kovvur) grown on carrot agar medium were used for recording the data radial growth of the mycelium at 7 days after inoculation (DAI), growth rate $(\mathrm{mm} /$ day), dry weight $(\mathrm{mg})$ and the data is presented in Table 3 .

\section{Colour of the colony}

The colour of the colony varied from dull white to white. Out of the 4 isolates, the colour of the isolate $\mathrm{PC}_{1}$ and isolate $\mathrm{PC}_{4}$ was white whereas the colony of isolate $\mathrm{PC}_{2}$ and isolate $\mathrm{PC}_{3}$ was dull white in colour.

\section{Growth of the colony}

The growth of the mycelium was measured at $24 \mathrm{hrs}$ interval and a variation was observed among the isolates which ranged from $72 \mathrm{~mm}$ to $88 \mathrm{~mm}$.

The maximum radial growth $(88 \mathrm{~mm})$ was recorded in isolate $\mathrm{PC}_{1}$ and minimum growth was observed in isolate $\mathrm{PC}_{2}(72 \mathrm{~mm})$. The growth of the colony was petal shaped in $\mathrm{PC}_{1}$ isolate whereas this character was not observed in other isolates.

\section{Colony growth rate}

All the four isolates of Phytophthora colocasiae differed in colony growth rate $(\mathrm{mm} /$ day) and it ranged from 10.3 to 12.6 $\mathrm{mm} /$ day. The isolate $\mathrm{PC}_{1}$ recorded mean maximum growth rate of $12.6 \mathrm{~mm} /$ day and minimum growth rate of 10.3 was observed in isolate $\mathrm{PC}_{2}$. 


\section{Abundance of mycelium}

Four isolates of Phytophthora colocasiae were grouped into 2 based on abundance of mycelium produced by Phytophthora colocasiae. The isolate $\mathrm{PC}_{2}$ from Bahadurguda produced profuse growth of mycelium, whereas isolates $\mathrm{PC}_{1}, \mathrm{PC}_{3}$ and $\mathrm{PC}_{4}$ from Rajendranagar, Thiruvanantapuram and Kovvuru produced slightly sparse mycelial growth.

\section{Colony texture}

Based on the texture and appearance of the colony, the isolates were categorized into two groups i.e. fluffy and slightly fluffy appearance of the colony on carrot agar medium. The isolates $\mathrm{PC}_{1}$ (Rajendranagar), $\mathrm{PC}_{3}$ (Thiruvanantapura), $\mathrm{PC}_{4}$ (Kovvuru) produced slightly fluffy colony whereas $\mathrm{PC}_{2}$ (Bahadurguda) produced thick fluffy colony

\section{Dry weight}

For dry weight of mycelium of Phytophthora colocasiae the pure culture was inoculated on Carrot agar broth $(\mathrm{CAB})$ and 10 days after inoculation the dry weight of the mycelium was recorded and the data was presented in Table 3. Isolate $\mathrm{PC}_{1}$ recorded maximum dry weight of $(282 \mathrm{mg})$ followed by isolate $\mathrm{PC}_{4}$ $(256 \mathrm{mg})$ and $\mathrm{PC}_{3}(181 \mathrm{mg})$. Minimum dry weight was recorded by isolate $\mathrm{PC}_{2}(152 \mathrm{mg})$.

Table.1 Isolates of Phytophthora colocasiae collected from different parts of Andhra Pradesh and Kerala

\begin{tabular}{|c|c|c|c|}
\hline S. No. & Isolates & Place and Mandal & District and state \\
\hline 1. & $\mathrm{PC}_{1}$ & Rajendranagar & Hyderabad, Andhra Pradesh \\
\hline 2. & $\mathrm{PC}_{2}$ & Bahadurguda, Moinabad & Ranga Reddy, Andhra Pradesh \\
\hline 3. & $\mathrm{PC}_{3}$ & Sreekariyam, Thiruvananthapuram & Thiruvananthapuram, Kerala \\
\hline 4. & $\mathrm{PC}_{4}$ & Kovvuru & West Godavari, Andhra Pradesh \\
\hline
\end{tabular}

Table.2 Effect of different media on radial growth of Phytophthora colocasiae

\begin{tabular}{|c|c|c|}
\hline S. No. & Name of the media & Radial growth $(\mathbf{m m})$ \\
\hline 1. & Carrot agar & 86.0 \\
\hline 2. & Carrot potato agar & 79.6 \\
\hline 3. & Papaya sucrose agar & 80.6 \\
\hline 4. & Host leaf extract agar & 72.0 \\
\hline 5. & Oat meal agar & 52.0 \\
\hline 6. & Potato dextrose agar & 22.0 \\
\hline 7. & Corn meal agar & 28.6 \\
\hline 8. & Water agar & 50.6 \\
\hline & CD at 5\% & 5.92 \\
\hline & SEm \pm & 11.70 \\
\hline & CV\% & 5.79 \\
\hline
\end{tabular}


Table.3 Colony characteristics of different isolates of Phytophthora colocasiae

\begin{tabular}{|c|c|c|c|c|c|c|c|c|}
\hline S. No. & Name of the Place & $\begin{array}{c}\text { Name of } \\
\text { the } \\
\text { isolate }\end{array}$ & $\begin{array}{c}\text { Colour } \\
\text { of the } \\
\text { colony }\end{array}$ & $\begin{array}{c}\text { Radial } \\
\text { growth of } \\
\text { the colony } \\
\text { (mm) }\end{array}$ & $\begin{array}{c}\text { Growth } \\
\text { rate/day } \\
\text { (mm) }\end{array}$ & $\begin{array}{c}\text { Texture } \\
\text { of } \\
\text { colony }\end{array}$ & $\begin{array}{c}\text { Abundance } \\
\text { of mycelium }\end{array}$ & $\begin{array}{c}\text { Dry weight } \\
\text { of } \\
\text { mycelium } \\
(\mathbf{m g})\end{array}$ \\
\hline 1. & Hyderabad & $\mathrm{PC}_{1}$ & White & 88.0 & 12.6 & $\begin{array}{c}\text { Slightly } \\
\text { fluffy }\end{array}$ & Sparse & 282 \\
\hline 2. & Ranga Reddy & $\mathrm{PC}_{2}$ & $\begin{array}{c}\text { Dull } \\
\text { white }\end{array}$ & 72.0 & 10.3 & Fluffy & Profuse & 152 \\
\hline 3. & Thiruvananthapuram & $\mathrm{PC}_{3}$ & $\begin{array}{c}\text { Dull } \\
\text { white }\end{array}$ & 80.0 & 11.4 & $\begin{array}{c}\text { Slightly } \\
\text { fluffy }\end{array}$ & Sparse & 181 \\
\hline 4. & West Godavari & $\mathrm{PC}_{4}$ & White & 82.0 & 11.7 & $\begin{array}{c}\text { Slightly } \\
\text { fluffy }\end{array}$ & Sparse & 256 \\
\hline
\end{tabular}

Table.5 Morphological variability of sporangium, oospore and zoospore among four isolates of Phytophthora colocasiae

\begin{tabular}{|c|c|c|c|c|c|c|c|c|c|c|c|c|}
\hline \multirow{2}{*}{ S. No. } & \multirow[t]{2}{*}{ Isolate } & \multicolumn{3}{|c|}{$\begin{array}{l}\text { Sporangium length } \\
(\text { um) }\end{array}$} & \multicolumn{3}{|c|}{$\begin{array}{c}\text { Sporangium width } \\
(\mu \mathrm{m})\end{array}$} & \multirow[t]{2}{*}{$\begin{array}{c}\text { L:B } \\
\text { ratio }\end{array}$} & \multirow{2}{*}{$\begin{array}{c}\text { Size of the } \\
\text { sporangium } \\
\left(\mu \mathrm{m}^{2}\right)\end{array}$} & \multicolumn{2}{|c|}{ Oospore } & \multirow{2}{*}{$\begin{array}{c}\text { Size of the } \\
\text { Zoospore } \\
\left(\mu \mathrm{m}^{2}\right)\end{array}$} \\
\hline & & Min. & Max. & Mean & Min. & Max. & Mean & & & $\begin{array}{c}\text { Mean } \\
\text { diameter } \\
(\mu \mathrm{m})\end{array}$ & $\begin{array}{c}\text { Size of } \\
\text { oospore } \\
\left(\mu^{2}\right)\end{array}$ & \\
\hline 1. & $\mathrm{PC}_{1}$ & 15.21 & 25.35 & 21.8 & 10.14 & 20.28 & 15.7 & $1.4: 1$ & 342 & 27.8 & 772.5 & 44 \\
\hline 2. & $\mathrm{PC}_{2}$ & 15.21 & 25.35 & 21.2 & 10.14 & 20.28 & 14.9 & $1.4: 1$ & 312 & 27.0 & 731.6 & 44 \\
\hline 3. & $\mathrm{PC}_{3}$ & 20.28 & 30.42 & 24.3 & 15.21 & 20.28 & 17.2 & $1.4: 1$ & 417 & 19.2 & 486.7 & 48 \\
\hline 4. & $\mathrm{PC}_{4}$ & 15.21 & 23.8 & 23.8 & 10.14 & 20.28 & 15.7 & $1.5: 1$ & 373 & 22.8 & 519 & 52 \\
\hline
\end{tabular}


Table.4 Morphological characteristics of sporangia and sporangiophores of different isolates of Phytophthora colocasiae

\begin{tabular}{|c|c|c|c|c|c|c|c|}
\hline S. No. & Isolate & Sporangia & $\begin{array}{c}\text { Stalked } \\
\text { / sessile }\end{array}$ & $\begin{array}{c}\text { Shape of } \\
\text { sporangium }\end{array}$ & Sporangiophores & $\begin{array}{c}\text { Hyphal } \\
\text { swellings }\end{array}$ & $\begin{array}{c}\text { Hyphal } \\
\text { width }(\boldsymbol{\mu m})\end{array}$ \\
\hline 1. & $\mathrm{PC}_{1}$ & Semi papillate & Stalked & Globose & Simple sympodial & Absent & 1 \\
\hline 2. & $\mathrm{PC}_{2}$ & Semi papillate & Stalked & Globose & Branched sympodial & Absent & 1 \\
\hline 3. & $\mathrm{PC}_{3}$ & Semi papillate & Stalked & Globose & Simple sympodial & Absent & 1 \\
\hline 4. & $\mathrm{PC}_{4}$ & Papillate & Stalked & Ovoid & Branched sympodial & Absent & 1 \\
\hline
\end{tabular}

(a)
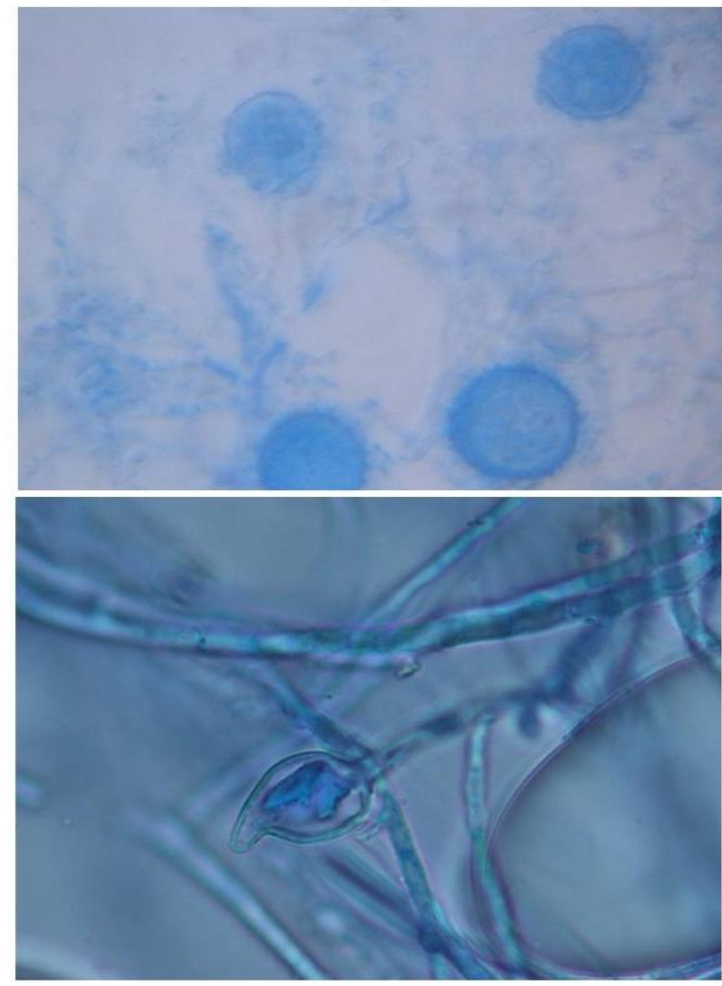

(c) (b)
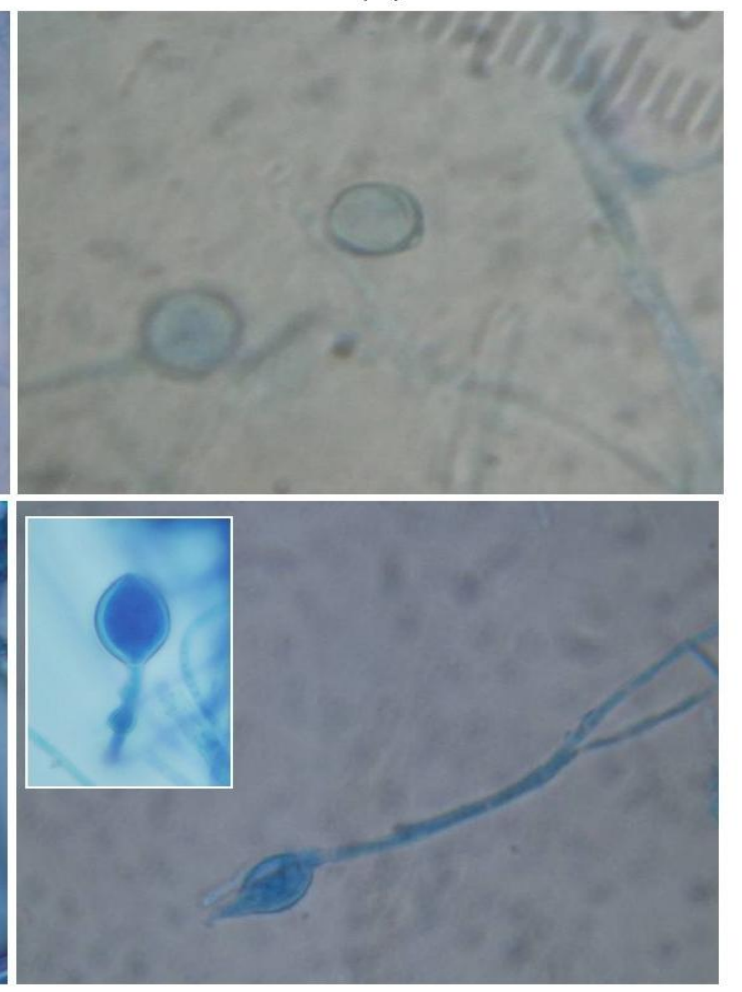

(d)

Plate 4.6. Sporangial characteristics of Phytophthora colocasiae observed by compound microscope (40X)
a) Semi papillate sporangia in isolate $\mathrm{PC} 1$
b) Semi papillate sporangia in isolate $\mathrm{PC} 2$
c) Semi papillate sporangia in isolate $\mathrm{PC} 3$
d) Papillate sporangia in isolate $\mathrm{PC} 4$ 


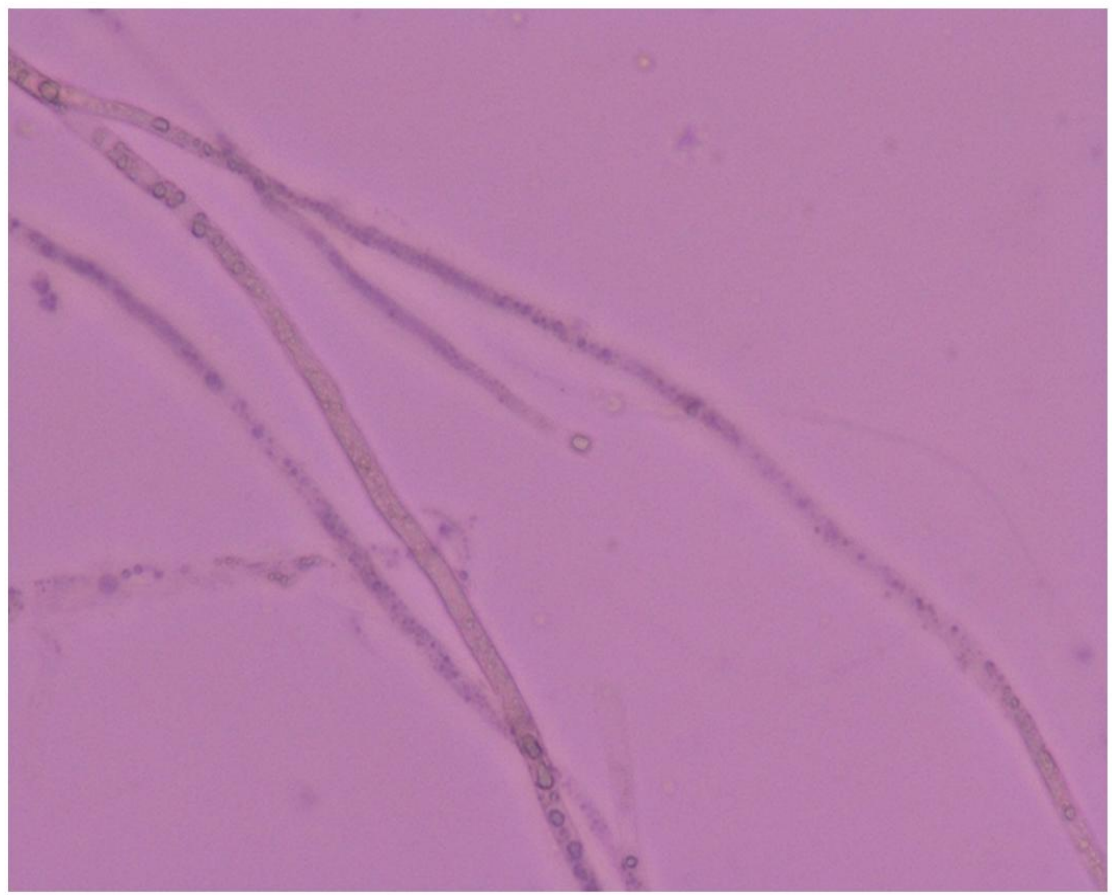

a) Aseptate Mycelium

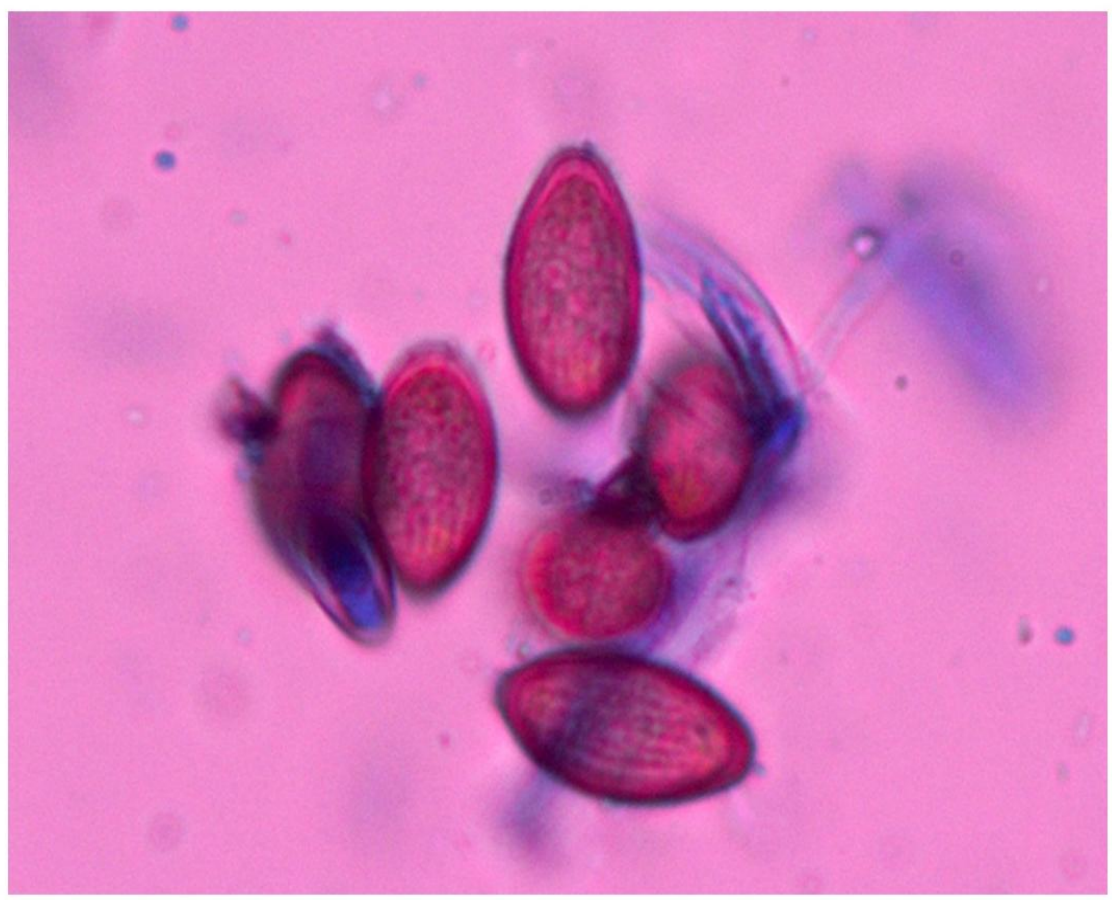

b) Semi papillate sporangia

Plate 4.7. Morphological characterstics of Phytophthora colocasiae observed by compound microscope (400X)

a) Aseptate mycelium

b) Semi papillate sporangia 


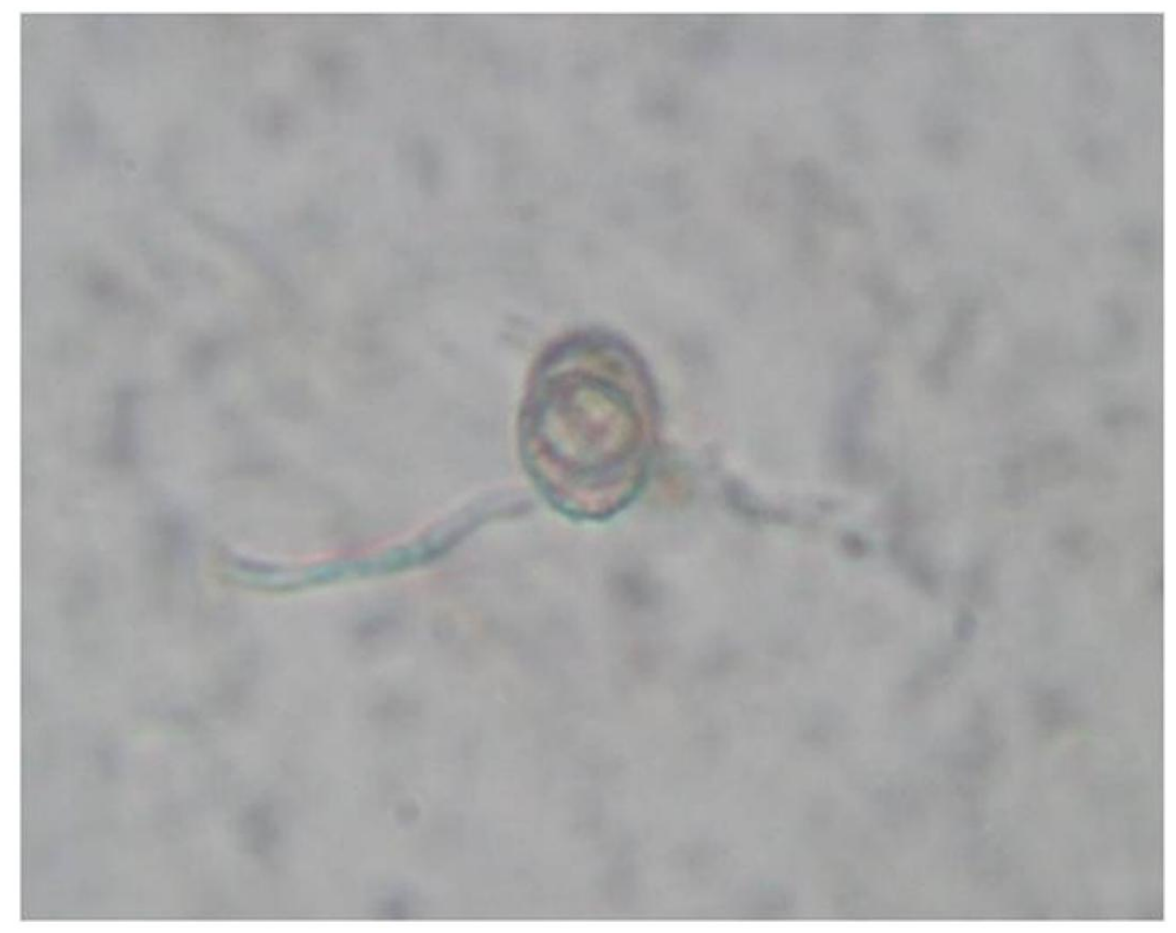

Plate 4.9. Formation of oospore in Phytophthora colocasiae observed under compound microscope (40X)

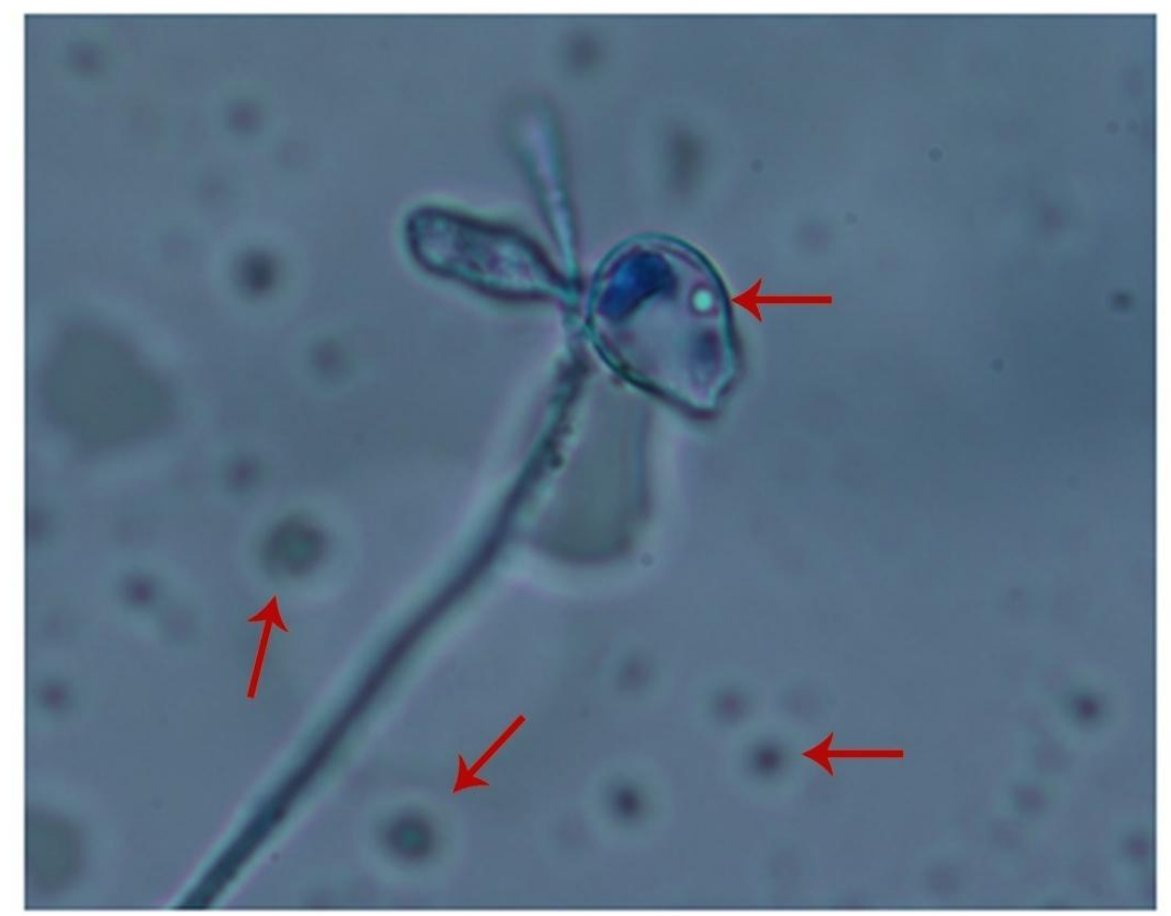

Plate 4.10. Release of zoospores from sporangium of Phytophthora colocasiae observed under compound microscope (400X) 

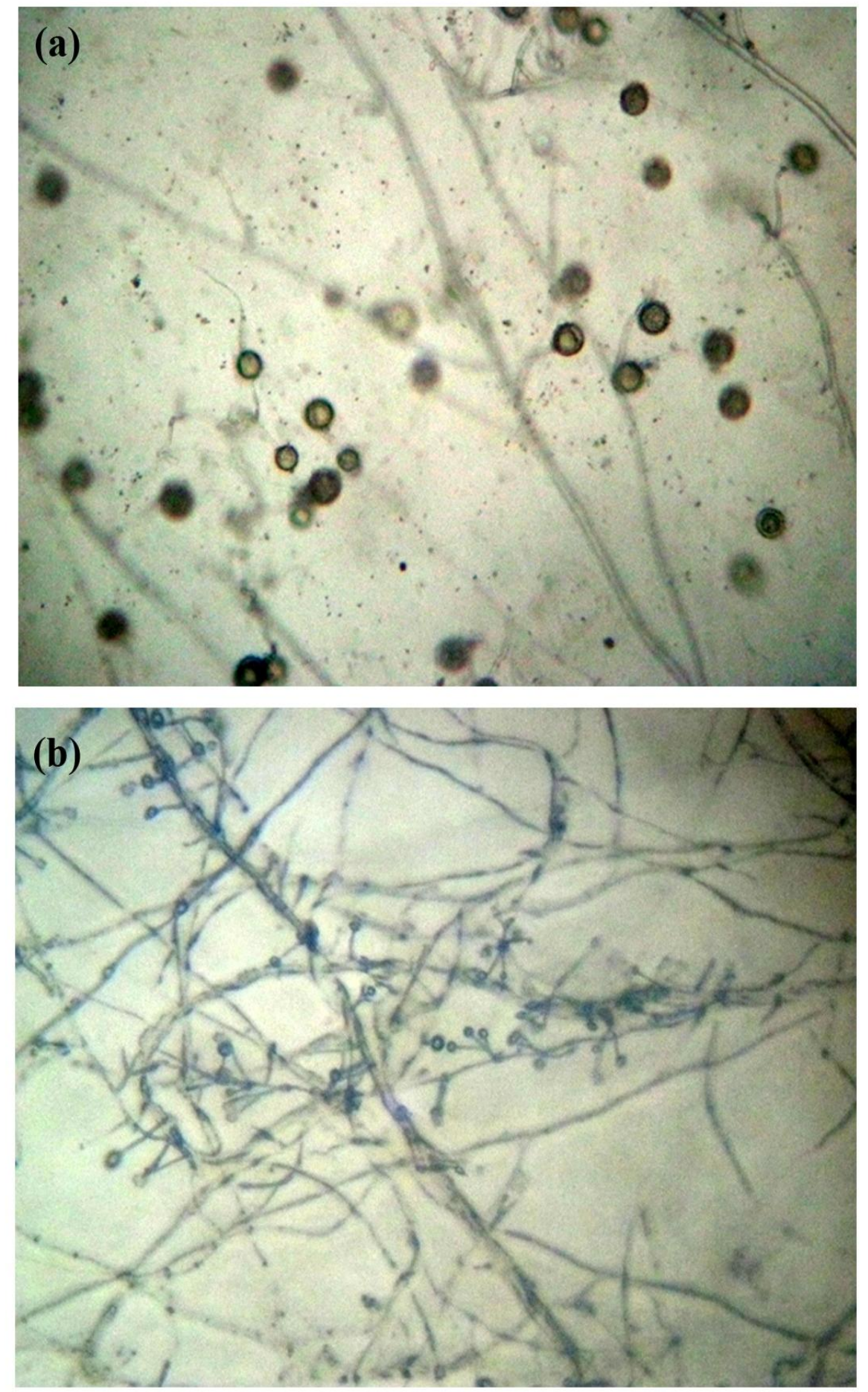

Plate 4.8. Sporangiophore characteristics of Phytophthora colocasiae observed by compound microscope (40X)

a) Simple sympodial sporangiophore of isolate PC 1 and PC 3

b) Branched sympodial sporangiophore of isolate PC 2 and PC 4 
Morphological characteristics of different isolates of Phytophthora colocasiae

\section{Sporangial characters}

Sporangial characters like size of sporangium, shape, presence or absence of papillae, variation in length, width and their ratio and size of oospore was studied for all the isolates of Phytophthora colocasiae using Olympus microscope at a magnification of $40 \mathrm{X}$ and the data pertaining to sporangial characters are indicated in Tables 4 and 5.

\section{Length of sporangium}

The mean sporangial length of 4 isolates of Phytophthora colocasiae ranged from $21.2 \mu \mathrm{m}$ to $24.3 \mu \mathrm{m}$. The maximum length of sporangia was recorded in isolate $\mathrm{PC}_{3}(24.3 \mu \mathrm{m})$ followed by $\mathrm{PC}_{4}(23.8 \mu \mathrm{m})$ while minimum length of sporangium was observed in isolate $\mathrm{PC}_{2}$ with $21.2 \mu \mathrm{m}$ and was on par with isolate $\mathrm{PC}_{1}$ which recorded a sporangial length of $21.8 \mu \mathrm{m}$.

\section{Width of sporangium}

The mean width of 4 isolates of Phytophthora colocasiae ranged from $14.9 \mu \mathrm{m}$ to $17.2 \mu \mathrm{m}$. The maximum width of sporangium was recorded in isolate $\mathrm{PC}_{3}(17.2 \mu \mathrm{m})$ and a minimum width of $14.9 \mu \mathrm{m}$ was recorded in isolate $\mathrm{PC}_{2}$, whereas isolates $\mathrm{PC}_{1}$ and $\mathrm{PC}_{4}$ showed a mean width of $15.7 \mu \mathrm{m}$.

\section{Length and width ratio}

Maximum length and width ratio of Phytophthora colocasiae isolates was recorded in isolate $\mathrm{PC}_{4}(1.5 \mu \mathrm{m})$ collected from East Godavari district (Kovvuru mandal), while in other isolates i.e., $\mathrm{PC}_{1}, \mathrm{PC}_{2}$ and $\mathrm{PC}_{3}$ the length and width ratio was 1.4:1.

\section{Size of the sporangium}

The isolates of Phytophthora colocasiae showed variation in size of the sporangium. The sporangial size varied from $312 \mu \mathrm{m}^{2}$ to 417 $\mu \mathrm{m}^{2}$. Maximum size $417 \mu \mathrm{m}^{2}$ was observed in isolate $\mathrm{PC}_{3}$ and minimum size of the sporangium was recorded in isolate $\mathrm{PC}_{2}$ with $312 \mu \mathrm{m}^{2}$. The size of the sporangium of isolate $\mathrm{PC}_{1}$ was $342 \mu \mathrm{m}^{2}$ while the size was $373 \mu \mathrm{m}^{2}$ in isolate $\mathrm{PC}_{4}$.

\section{Shape of the sporangium}

The shape of the sporangium of three isolates of Phytophthora colocasiae $\mathrm{PC}_{1}, \mathrm{PC}_{2}$ and $\mathrm{PC}_{3}$ were globose, semi papillate whereas the sporangium of isolate $\mathrm{PC}_{4}$ was ovoid and papillate (Plate 4.6).

\section{Sporangiophore}

The sporangiophore of isolates $\mathrm{PC}_{1}$ and $\mathrm{PC}_{3}$ were simple sympodial whereas branched sympodial sporangiophore was observed in isolates $\mathrm{PC}_{2}$ and $\mathrm{PC}_{4}$ (Plate 4.8).

The hyphal swellings were absent in all the four isolates of Phytophthora colocasiae and a hyphal width of $1 \mu \mathrm{m}$ was also recorded in all the four isolates of Phytophthora colocasiae.

\section{Size of oospore}

A variation in the size of the oospore was observed among the four isolates of Phytophthora colocasiae (Plate 4.9). The maximum size of the oospore was recorded in isolate $\mathrm{PC}_{1}$ with $772.5 \mu \mathrm{m}^{2}$ with mean diameter of $27.8 \mu \mathrm{m}^{2}$ followed by isolate $\mathrm{PC}_{2}(731.6$ $\mu \mathrm{m}^{2}$ ) with $27.0 \mu \mathrm{m}^{2}$ diameter and the minimum size of the oospore was recorded in isolate $\mathrm{PC}_{4}$ $\left(519 \mu \mathrm{m}^{2}\right)$ followed by isolate $\mathrm{PC}_{3}\left(486.7 \mu \mathrm{m}^{2}\right)$ with $19.2 \mu \mathrm{m}^{2}$ and $22.8 \mu \mathrm{m}^{2}$ mean diameter respectively

\section{Zoospores}

The size of the zoospores varied from $44 \mu \mathrm{m}$ $52 \mu \mathrm{m}$ which were biflagellate and slender. The size of the zoospore in isolate $\mathrm{PC}_{1}$ and $\mathrm{PC}_{2}$ was $44 \mu \mathrm{m}$ followed by isolate $\mathrm{PC}_{3}$ which was 48 $\mu \mathrm{m}$ and maximum size of zoospore was observed in isolate $\mathrm{PC}_{4}$ with $52 \mu \mathrm{m}$ 
Similar observations were made by Misra (1996) in P. colocasiae. The zoosporangiophores were slender, cylindrical and extremely narrow at the tip and measured up to $50 \mu \mathrm{m}$ in length. The zoosporangia were elongated lemon or pear shaped and generally measured $38-60 \mu \mathrm{m} \times 18-26 \mu \mathrm{m}$ and zoosporangial length over $100 \mu \mathrm{m}$ and width over $50 \mu \mathrm{m}$ were recorded.

Bandyopadhyay et al., (2011) reported that the sporangia of $P$. colocasiae were hyaline, papillate and measured 25 to $55 \mu \mathrm{m} \times 15$ to 30 $\mu \mathrm{m}$. Zoospores encysted within $30 \mathrm{~min}$. after release and size of the cyst was $9.7 \mu \mathrm{m}$ to 19.5 $\mu \mathrm{m}$ in diameter.

Omane et al., (2012) reported morphological characters of $P$. colocasiae isolates of taro from Ghana. Sporangia were ovoid, hyaline, papillate, caduceus, 30 to $60 \mu \mathrm{m} \times 17$ to $28 \mu \mathrm{m}$, and pedicels were $3.5 \mu \mathrm{m}$ to $10 \mu \mathrm{m}$ long.

These results also confirmed the present findings that the sporangia were globose in three isolates except in isolate $\mathrm{PC}_{4}$ which was ovoid.

This study confirms that isolates of $P$. colocasiae are highly dynamic in nature and a considerable degree of diversity exists among them. A detailed knowledge of the morphological characters of $P$. colocasiae will help in developing suitable control strategies against the taro leaf blight disease

\section{References}

Bandyopadhyay, R., Sharma, K., Onyeka T. J., Aregbesola, A and Lava Kumar, P. 2011. First report of Taro (Colocasia esculenta) leaf blight caused by Phytophthora colocasiae in Nigeria. Plant disease. 95 (5): 618

Butler, E. J., and Kulkarni, G. S. 1913. Colocasia blight caused by Phytophthora colocasiae Racib. Memoirs: Department of Agriculture. India. 5: 223-259.

Hemmes, D. E., 1993. In Phytophthora - Its Biology, Taxonomy, Ecology and Pathology (Eds. Erwin, D.C., Bartmick, Garcia S, and Tsao, P.H.) American Phytopathological Society, St. Paul, Minnesota USA. 19- 40

Lakshmi, B.K.M., Reddy, R.V.S.K and Dilip Babu, J. 2012. Impact of weather parameters on the incidence of leaf blight disease in Taro (Colocasia esculenta (L.) Schott.) Journal of Root Crops. 38 (1): 93-96.

Misra, R.S., 1996. A note on zoosporogenesis in Phytophthora colocasiae. Indian Phytopathology. 49 (1): 80-82

Misra, R.S., Maheshwari, S.K., Sriram, S., Sharma, K and Sahu, A.K. 2007. Integrated management of Phytophthora leaf blight disease of Taro. Journal of Root Crops. 33

Omane, E., Oduro, A and Cornelius, E.W. 2012. First report of leaf blight of taro (Colocasia esculenta) caused by Phytophthora colocasiae in Ghana. Plant Disease. 96 (2): 292-293.

Palomar, M.K., Mangaoang, Y.C., Palermo, V.G and Edurise, G. 1999. Evaluation of culture media for sporangial production of Pytophthora colocasiae L. and control of taro blight using fungal antaonists. Phytopathology. 35: 8-16

Waterhouse, Grace M., 1963. Key to the species of Phytophthora de Bary. UK: Common Wealth Agricultural Bureaux. Mycological Papers. No. 92.

\section{How to cite this article:}

Padmaja, G., G. Uma Devi, B. Kanaka Mahalakshmi and Sridevi, D. 2017. Characterization of Isolates of Phytophthora colocasiae Collected from Andhra Pradesh and Telangana Causing Leaf Blight of Taro. Int.J.Curr.Microbiol.App.Sci. 6(10): 1901-1912. doi: https://doi.org/10.20546/ijcmas.2017.610.229 